\title{
Current surgical management for acute empyema
}

Empyema has been known since ancient times and is still an intractable pleural infection. Because pleural infections may be related to the resultant socioeconomic change brought about by an increasingly aging society, the incidence of empyema will likely increase (1). It has been reported that $70 \%$ of parapneumonic effusions (PEs) are the cause of empyema (2). With respect to the progression of pleural infections, PE is stage $\mathrm{I}$, fibrinopurulent stage is stage II, and chronic organization is stage III. Indeed, progression of a pleural infection to a loculation occurs following several hours of free-flowing fluid (3). During the process, a free-flowing exudate changes to fibrin loculation and eventually to collagen formation. Although antibiotics are the primary treatment for pleural infections, chest tube drainage is recognized as fundamental and essential for the management of acute empyema. Patients with empyema and a fluid collection require chest tube drainage, otherwise entrapped lung and surgical decortication would be performed. For patients who have a PE or empyema, a prompt decision to intervene is needed without hesitation. In spite of antibiotic treatment and intervention, the in-hospital 30-day mortality has been reported to be $7-11 \%$ (4).

The treatment of empyema varies and controversies exist. The success rate with chest tube drainage is $40 \%$ (5). Because loculated pleural effusions and fibrin deposition occur in complicated PEs or the fibrinopurulent stage, chest tube drainage might not be effective. Wozniak et al. (5) reported that failure of the first procedure is an independent risk factor for mortality. After chest tube drainage and administration of antibiotics, there are mixed opinions regarding the choice of surgery or fibrinolytic therapy. According to a recent study in the United States, among patients who underwent surgical intervention for empyema, chest tubes were placed in $38.2 \%$, video-assisted thoracic surgery (VATS) decortication and drainage was performed in $32.1 \%$, and open decortication and drainage was performed in $29.8 \%$ (6). This report revealed that higher readmission $(7.3 \%)$ and re-intervention rates $(6.2 \%)$ occurred in the patients with an empyema who underwent chest tube drainage alone (6).

According to a population-based analysis, patients who underwent surgery had a $58 \%$ lower risk of death than patients who underwent non-surgical management (1). Of note, however, surgical cases tend to be younger and have a lower comorbidity rate (1). Because the retrospective studies had selection bias, the scientific evidence is not sufficient to date. Thus, the evaluation of surgical cases should be carefully interpreted. Two randomized control studies compared VATS with chest tube drainage $(7,8)$. The sample size in both studies was small and it is possible that the empyema stage affected the surgical outcome. Indeed, there are no robust studies demonstrating scientific evidence of VATS superiority. The essential concept of treatment for an empyema is appropriate antibiotics and chest tube drainage. Additionally, chest tube drainage facilitates removal of the pleural effusion and pus, and promotes lung re-expansion to reduce the dead space of the pleural cavity. The purpose of surgery is to disrupt pleural adhesions and achieve lung re-expansion.

Empyema outcomes are affected by prompt decision-making regarding antibiotic administration or chest tube drainage. Delayed pleural space drainage could lead to a prolonged hospital stay. Additionally, co-morbidities and the background of the patient should be carefully considered for treatment selection. If chest tube drainage is not effective, prompt surgical intervention for empyema should be considered. The difficulty of VATS surgery for empyema is increased by a longer duration of symptoms, and the possibility of conversion from VATS to open thoracotomy is increased (4).

This series of the Current Challenges in Thoracic Surgery is dedicated to the surgical management of empyema. The authors discussed the problems and perspectives of empyema treatment. Because an empyema is too complex to standardize treatment, we must individualize the treatment based on co-morbidities and patient background.

\section{Acknowledgments}

Funding: None.

\section{Footnote}

Provenance and Peer Review: This article was commissioned by the editorial office, Current Challenges in Thoracic Surgery, for 
the series "Empyema". The article did not undergo external peer review.

Conflicts of Interest: The author has completed the ICMJE uniform disclosure form (available at https://ccts.amegroups.com/ article/view/10.21037/ccts-2020-emp-04/coif). The series "Empyema" was commissioned by the editorial office without any funding or sponsorship. SS served as the unpaid Guest Editor of the series, and serves as an unpaid editorial board member of Current Challenges in Thoracic Surgery from September 2019 to August 2021.

Ethical Statement: The author is accountable for all aspects of the work in ensuring that questions related to the accuracy or integrity of any part of the work are appropriately investigated and resolved.

Open Access Statement: This is an Open Access article distributed in accordance with the Creative Commons AttributionNonCommercial-NoDerivs 4.0 International License (CC BY-NC-ND 4.0), which permits the non-commercial replication and distribution of the article with the strict proviso that no changes or edits are made and the original work is properly cited (including links to both the formal publication through the relevant DOI and the license). See: https://creativecommons.org/ licenses/by-nc-nd/4.0/.

\section{References}

1. Farjah F, Symons RG, Krishnadasan B, et al. Management of pleural space infections: a population-based analysis. J Thorac Cardiovasc Surg 2007;133:346-51.

2. Sahn SA. Diagnosis and management of parapneumonic effusions and empyema. Clin Infect Dis 2007;45:1480-6.

3. Sahn SA, Light RW. The sun should never set on a parapneumonic effusion. Chest 1989;95:945-7.

4. Godfrey MS, Bramley KT, Detterbeck F. Medical and Surgical Management of Empyema. Semin Respir Crit Care Med 2019;40:361-74.

5. Wozniak CJ, Paull DE, Moezzi JE, et al. Choice of first intervention is related to outcomes in the management of empyema. Ann Thorac Surg 2009;87:1525-30; discussion 1530-1.

6. Semenkovich TR, Olsen MA, Puri V, et al. Current State of Empyema Management. Ann Thorac Surg 2018;105:1589-96.

7. Wait MA, Sharma S, Hohn J, et al. A randomized trial of empyema therapy. Chest 1997;111:1548-51.

8. Bilgin M, Akcali Y, Oguzkaya F. Benefits of early aggressive management of empyema thoracis. ANZ J Surg 2006;76:120-2. 


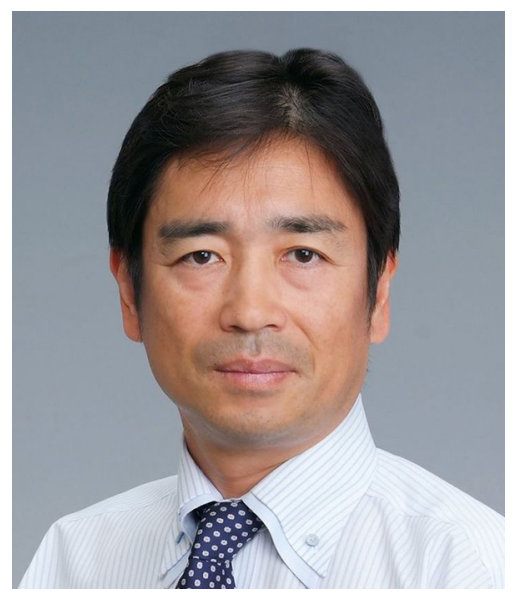

Satoshi Shiono

Satoshi Shiono, MD, PhD

Department of Thoracic Surgery, Yamagata Prefectural Central Hospital, Yamagata, Fapan. (Email: sshiono@ypch.gr.jp) Received: 09 September 2020; Accepted: 20 September 2020; Published: 25 May 2021. doi: $10.21037 /$ ccts-2020-emp-04

View this article at: http://dx.doi.org/10.21037/ccts-2020-emp-04

doi: $10.21037 /$ ccts-2020-emp-04

Cite this article as: Shiono S. Current surgical management for acute empyema. Curr Chall Thorac Surg 2021;3:12. 